THROUGH

JAUNDICED

EYES 



\title{
THROUGH \\ JAUNDICED \\ EYES
}

\section{How the Media View Organized Labor}

\author{
William J. Puette
}

\section{ILR Press}

Ithaca, New York 
Copyright (C) 1992 by Cornell University

All rights reserved.

Cover design by Marcelle Toor

Library of Congress Cataloging-in-Publication Data

Puette, William J.

Through jaundiced eyes : how the media view organized labor /

William J. Puette.

p. $\mathrm{cm}$.

Includes bibliographical references and index.

ISBN 0-87546-184-0 (acid-free paper). — ISBN 0-87546-185-9

(pbk.: acid-free paper)

1. Trade-unions and mass media-United States. 2. Trade-unions in the press-United States. 3. Industrial relations in the pressUnited States. 4. Employees-United States-Public opinion.

5. Trade-unions-United States-Public opinion. I. Title. P96.T7P84 1992

$331.88^{\prime} 0973-\mathrm{dc} 20$

$91-46351$

Copies may be ordered through bookstores or directly from:

ILR Press

CUP Services

P.O. Box 6525

Ithaca, NY 14851

(607) 277-2211

Printed on acid-free paper in the United States of America $\begin{array}{lll}5 & 4 & 3\end{array}$ 